to meet with a similar committee of the Research Council to consider how such co-operation can be made most effective."

Among the committees appointed by the Executive Committee may be mentioned those on Research in sducational Institutions, on Promotion of Industrial Research, and on a National Census of Research.

It was agreed that joint committees on research in various branches of science be formed in co-operation with the corresponding national scientific societies.

In addition to the officers mentioned, Dr. C. D. Walcott and Dr. Gano Dunn have been appointed vicechairmen of the council.

\section{MINERAL RESOURCES OF THE BRITISH EMPIRE.}

PAPER on "The Mineral Resources of the British Empire with regard to the Production of the Non-Ferrous Industrial Metals," by Dr. C. Gilbert Cullis, professor of economic mineralogy in the Imperial College of Science and Technology, was read before the Society of Engineers on December I I.

The particular metals dealt with were copper, lead, zinc, tin, and aluminium. The object was to demonstrate the Imperial position with regard to each of these, and to show in respect of which of them the Empire was, on one hand, self-sufficing, or, on the other, dependent upon foreign countries. In the latter case the extent of the dependence was indicated, and methods suggested by which it might be diminished.

The situation with regard to four out of the five metals was shown to be wanting in independence and security, and the necessity for a full investigation of the British mine- and smelter-production was insisted upon.

With regard to copper, not only were the ore resources, as at present exploited, deficient, but the smelt. ing facilities also were seriously inadequate for the Empire's metal requirements. The production both of ores and metal could be substantially increased by suitable organisation and administration.

Lead and zinc ores, raised in British territory, had in the past been exported on a large scale to foreign countries, notably Germany and Belgium, for metal recovery, with the result that the Empire had been placed in an anomalous position of dependence which ought never to have arisen. The shortage of zinc, in the early days of the war, and the consequent jeopardising of supplies of cartridge-brass were referred to. The mine-production of lead and zinc was more than sufficient for the Empire's requirements, but the smelting facilities were lamentably deficient, especially in the case of zinc. It was urged that all the lead and zinc concentrates of Broken Hill should in future be smelted within the Empire.

In the case of aluminium, while the actual bauxite resources of the Empire were so small that dependence had to be placed upon the French or American deposits -which were being more and more utilised in their countries of origin-large potential supplies, in the form of laterite, had a very wide distribution in the tropical colonies, but were almost untouched and untried. The systematic examination of these and other potential sources of aluminium, with a view to their utilisation, was seriously needed.

The only metal with regard to which our position was really strong was tin. The British mine-production of tin in 1912 was 66,000 metric tons out of a world's total of 125,000, and the smelter-production 85,500 . Estimating the consumption at 32,500 tons, there remained 53,000 tons available for export. Now that the German market for Bolivian tin ore was NO. 2462 , VOL. 98$]$ closed, an opportunity had arisen of securing the whole of the Bolivian output for British smelting.

In a series of general conclusions, a plea was put forward for the elimination of wasteful methods in ore and metal recovery, for the fuller utilisation of byproducts from ores, and for the adoption of large-scale operations of high engineering efficiency by which capital and labour might be advantageously used. The widespread export of raw or partially smelted materials, produced within the Empire, to foreign countries for the recovery of the finished products was condemned, and the promotion of industries making for independ. ence as regards essential products advocated.

The expediting of geological and mineral surveys of all British territory, and the organisation of advance investigations with the object of improving current processes, or of discovering new ones by which geological materials hitherto unexploitable might be made productive, were urged.

The development of the mineral resources of the Empire had taken place in the past without any constructive Imperial policy; it had lacked co-ordination and control, and was in need of scientific and businesslike administration, and the suggestion that a Govern. ment Department of Minerals and Metals should be established to foster and safeguard British mineral resources and to promote the welfare of related industries was strongly supported. If formed and properly conducted, such a department should do much to give security and order to what was now full of danger and disorder.

\section{UNIVERSITY AND EDUCATIONAL INTELLIGENCE.}

Mr. A. Shepard Churchill, who died on October i8, leaving estate of the value of $109,495 l$., bequeathed $50,000 l$. to Harrow School for two scholarships, one on the classical and one on the modern side, of the clear yearly value of $150 l$. each, to be known as the "Shepard Churchill" scholarships, tenable at any college at Oxford for four years. In the election regard is to be had to literary and scholastic attainments, fondness and success in manly outdoor sports, such as cricket and football, qualities of manliness, courage, truthfulness, devotion to duty, sympathy with and readiness to protect the weak, kindness, unselfishness, and love of comrades; exhibition during school days of force of character and of instincts leading to the exercise of good and kindly influence over schoolfellows. There are also to be founded four entrance scholarships of $120 l$. each for two modern and two classical students. The residue of the property is also left for the benefit of Harrow School in such manner as the governors, with the approval of the headmaster, shall direct. The total bequest is expected to amount to $100,000 l$.

IN an important letter published in the Electrician for December 15, I916, Mr. A. Gray of Cornell University, points out that the American electrical engineering firms are in much closer touch with the teachers of electrical engineering than British firms desire to be according to Mr. J. Swinburne. The Westinghouse Electric Company takes in a large number of university graduates each year, and the officials of the com. pany, in order to improve the graduates they receive, have instituted summer schools for teachers, of whom thirty are selected and assigned to special departments in which they work from $8 \mathrm{a} . \mathrm{m}$. to $5 \mathrm{p} . \mathrm{m}$. They are paid about $12 l$. for five weeks' service, and are allowed to visit any part of the works. In his department the teacher is generally given some problem to solve which has had to be put aside owing to the limited time at the disposal of the regular staff. The 